\title{
Water Quality of Underground Wells in Limoeiro do Norte, Brazilian Northeast
}

\author{
Luma Lorena L. S. Rodrigues ${ }^{1}$, Eulene F. Silva ${ }^{1}$, Milene L. Farias ${ }^{1}$, Antônio M. Pinheiro ${ }^{1}$, Renner B. Lima ${ }^{1}$, \\ Francimar M. S. Morais ${ }^{1}$, Eula Paula S. Santos ${ }^{1}$, Maria Carla S. Campêlo ${ }^{1}$, Larissa F. Silva ${ }^{1}$, \\ Diana F. Freitas ${ }^{2} \&$ Felipe O. Oliveira ${ }^{1}$ \\ ${ }^{1}$ University Federal Rural do Semi-Árido, Mossoró, Rio Grande do Norte, Brazil \\ ${ }^{2}$ University Federal Rural do Pernambuco, Serra Talhada Academic Unit, Pernambuco, Brazil \\ Correspondence: Eulene F. Silva, Department of Forestry and Agronomy Sciences, University Federal Rural do \\ Semi-Árido, Mossoró, Rio Grande do Norte, Brazil. E-mail: eulenesilva@ufersa.edu.br
}

Received: July 9, 2019 Accepted: August 17, $2019 \quad$ Online Published: October 15, 2019

doi:10.5539/jas.v11n17p251 URL: https://doi.org/10.5539/jas.v11n17p251

\begin{abstract}
The objective of this work was to assess the physicochemical and microbiological characteristics, as well as the potential of salinization and sodification of groundwater wells in Limoeiro do Norte, Ceará states, Brazil. Six water wells were selected for the study, all of them used for irrigation and human consumption. The ionic classification was performed by Piper Diagram and the salinity risk using the U.S.S.L. (United States Salinity Laboratory) Diagram using Qualigraf software. Based on the average chemical element concentration $\left(\mathrm{mmol}_{\mathrm{c}} \mathrm{L}^{-1}\right)$ in the groundwater, the following quantification is obtained: $\mathrm{Na}^{+}>\mathrm{Ca}^{2+}>\mathrm{Mg}^{2+}>\mathrm{K}^{+}$for cations. For anions there was a change in the the wells, for the 1,3 and $4 \mathrm{Cl}^{-}>\mathrm{HCO}_{3}{ }^{-}>\mathrm{SO}_{4}{ }^{2-}>\mathrm{CO}_{3}{ }^{2-}$ and wells 2,5 and $6 \mathrm{HCO}_{3}{ }^{-}>$ $\mathrm{Cl}^{-}>\mathrm{SO}_{4}{ }^{2-}>\mathrm{CO}_{3}{ }^{2-}$. The wells 1,2 and 3 have severe restrictions for use by SAR (sodium absorption ratio) and $\mathrm{Na}^{+}$content. Water from wells 1,3 and 5 were classified as sodium chloride, 2 and 6 were classified as sodium bicarbonate and well 4 as calcium magnesium sulfate. With the exception of well 6 classified as freshwater, all other wells were classified as brackish water. Groundwater samples fall in $\mathrm{C} 3 \mathrm{~S} 1$ or C3S2 category with high salinity and low or medium sodium hazard. With the exception of $\mathrm{Na}^{+}$, whose value was above the limit allowed, no well with groundwater was detected chemical hazard for human consumption. There was the detection of Total coliforms, but in well 5 the presence of Thermotolerant coliforms was detected.
\end{abstract}

Keywords: coliforms, piper's diagram, salinity, sodification, water hardness

\section{Introduction}

Although the earth has approximately $70 \%$ of its surface in water, $97.5 \%$ of this percentage is salt water. Of $2.5 \%$ of fresh water remaining, $29.9 \%$ of this percentage is of groundwater (Ministério do Meio Ambiente [MMA], 2018). The unsustainable use of water for the production of large-scale crops depletes and contaminates aquifers, reduces the flow of rivers, degrades the habitats of the life of the flora and fauna, decreasing the availability and quality of water resources (FAO, 2011). In Brazil, the annual gross amount of water extracted from aquifers, including the withdrawal of renewable primary and secondary groundwater, as well as water from over-abstraction of renewable groundwater or withdrawal from fossil groundwater has been estimated at $10^{9}$ $\mathrm{m}^{3} /$ year (2013-2017) (FAO, 2017).

Due to climatic conditions, characterized by short, irregular, concentrated rainfall, followed by dry periods, with high temperatures and high evaporation rates, typical of the semi-arid climate, reduces hydraulic recharge of rivers and increases water exploration groundwater. Associated with this, water demand has increased due to population growth, the need to produce more food and growth in the industrial sector, beyond qualitative deterioration of surface water resources, make groundwater extremely important, capable of functioning as a strategic reserve and influencing political-socioeconomic development of any community. The work López et al. (2019) in Masaya (Nicaragua) highlights the importance of carrying out water quality studies, especially in rural communities, where the continuous control of quality analytical parameters are scarce and in certain cases non-existent. These authors found a high concentration of total coliforms in the taps, mainly due to the filtration of anthropogenic or waste residues animals. 
Groundwater is less contaminated by biological and chemical factors than surface water resources because they are not exposure to pollution (Eckhardt, Diedrich, Ferreira, Strohschoen, \& Demaman, 2008). However, the water from these wells is not free from contamination, and the hazard of microbiologically contaminated water can be high. Research by Silva et al. (2014) supports that septic tanks, inadequate disposal of solid waste, fuel stations and modern agriculture using pesticides and fertilizers are responsible for the contamination of groundwater by pathogens (bacteria, viruses and protozoa) and by organic substances and inorganic.

In the region of Limoeiro do Norte, Ceará states, Northeast Brazil, groundwater resources are an important source potable water of supply for urban and rural communities. The wells in use with higher water availability were found in the Açu $\left(125.22 \mathrm{~m}^{3} \mathrm{~h}^{-1}\right)$, followed by Jandaíra $\left(112.36 \mathrm{~m}^{3} \mathrm{~h}^{-1}\right)$, Fissural $\left(41.46 \mathrm{~m}^{3} \mathrm{~h}^{-1}\right)$ and Aluvião $\left(11.83 \mathrm{~m}^{3} \mathrm{~h}^{-1}\right)$ aquiferes, the most explored being Aquifer Jandaíra (Morais, Rocha Filho, Cordeiro, Figueiredo, \& Rosa, 2005). The use of water from these wells has increased in recent years in this region due to irregularities in the rainy season and the decrease in average rainfall in the region.

Thus, physical-chemical and microbiological monitoring of groundwater quality is an important management tool, enabling decision making by environmental agencies and communities. The objective of this work was to analyze the physical, chemical and microbiological characteristics of groundwater and its hazard for salinization and sodification, in Limoeiro do Norte-CE, Brazilian semi-arid region.

\section{Method}

The research was conducted in the Municipality of Limoeiro do Norte, Ceará states, Brazilian semi-arid region, which is an integral part of the Baixo Jaguaribe watershed, located at $05^{\circ} 08^{\prime} 44^{\prime \prime} \mathrm{S}$ latitude and $38^{\circ} 05^{\prime} 53^{\prime \prime}$ W longitude, with altitude of $30 \mathrm{~m}$. The local climate was classified as BSh, according to Köppen, mean annual temperature of $26.5^{\circ} \mathrm{C}$. and annual rainfall less than $700 \mathrm{~mm}$, with o rainy period extends from February to June, and Caatinga vegetation (Alvares et al., 2014). Cretaceous sandstones and conglomerates (Açu Formation) and by Cretaceous limestones (Jandaíra Formation) represent the stratigraphy, that occurs in almost all its domain.

The criterion for selection of areas was established considering the site where underground wells were used for irrigation of some agricultural crops, as well as for human consumption. In this case, 1 well was selected in the urban area and 5 in the rural communities, whose description is shown in Table 1.

Table 1. Name of the property, location and history of soil management on the underground wells in Limoeiro do Norte, Ceará State, Brazil

\begin{tabular}{|c|c|c|c|c|c|}
\hline $\begin{array}{l}\text { Number of } \\
\text { underground wells }\end{array}$ & $\begin{array}{l}\text { Name of the } \\
\text { property }\end{array}$ & Location & Present crops & Previous crops & Soil management \\
\hline 1 & $\begin{array}{l}\text { Várzea do Cobra } \\
\text { rural community }\end{array}$ & $\begin{array}{l}5^{\circ} 07^{\prime} 35.8^{\prime \prime} \mathrm{S} \\
38^{\circ} 03^{\prime} 19.9^{\prime \prime} \mathrm{W}\end{array}$ & Fruit variety farming & Native forest & $\begin{array}{l}\text { Chemical and organic } \\
\text { fertilization; weed control }\end{array}$ \\
\hline 2 & $\begin{array}{l}\text { Quixaba rural } \\
\text { community } 1\end{array}$ & $\begin{array}{l}5^{\circ} 11^{\prime} 11.5^{\prime \prime} \mathrm{S} \\
38^{\circ} 06^{\prime} 21.6^{\prime \prime} \mathrm{W}\end{array}$ & Lemon farming & Banana & Organic fertilization \\
\hline 3 & $\begin{array}{l}\text { Quixaba rural } \\
\text { community } 2\end{array}$ & $\begin{array}{l}5^{\circ} 11^{\prime} 11.5^{\prime \prime} \mathrm{S} \\
38^{\circ} 06^{\prime} 31.6^{\prime \prime} \mathrm{W}\end{array}$ & Elephant grass; brachiaria & Lemon farming & Harrowing and plowing soil \\
\hline 4 & $\begin{array}{l}\text { Bom Fim rural } \\
\text { community }\end{array}$ & $\begin{array}{l}5^{\circ} 09^{\prime} 27.2^{\prime \prime} \mathrm{S} \\
38^{\circ} 05^{\prime} 27.7^{\prime \prime} \mathrm{W}\end{array}$ & Tifton grass & Banana & $\begin{array}{l}\text { Chemical and organic } \\
\text { fertilization }\end{array}$ \\
\hline 5 & $\begin{array}{l}\text { João Eudes rural } \\
\text { community }\end{array}$ & $\begin{array}{l}5^{\circ} 11^{\prime} 31.3^{\prime \prime} \mathrm{S} \\
38^{\circ} 06^{\prime} 30.5^{\prime \prime} \mathrm{W}\end{array}$ & Brachiaria & Native forest & $\begin{array}{l}\text { Harrowing and plowing soil; } \\
\text { Chemical fertilization. }\end{array}$ \\
\hline 6 & Urban area & $\begin{array}{l}5^{\circ} 08^{\prime} 58.4^{\prime \prime S} \\
38^{\circ} 05^{\prime} 27.7^{\prime \prime} \mathrm{W}\end{array}$ & $\begin{array}{l}\text { Fruit variety and } \\
\text { vegetable farming }\end{array}$ & Fruit variety farming & $\begin{array}{l}\text { Chemical and organic } \\
\text { fertilization; weed control }\end{array}$ \\
\hline
\end{tabular}

Data were collected in the dry season. For the collection of water from the underground wells, $500 \mathrm{ml}$ clear plastic pet bottles were used. Before collecting, the pet bottles were washed three times with the water from the sampling source and the water collected from wells after the water flow for 60 seconds. Chemical analysis carried out on electronic equipment were: $\mathrm{pH}$; Electric conductivity; potassium and sodium. The parameters alkalinity, total hardness, calcium, magnesium, chloride and carbonates were determined by the titrator method. All chemical analyzes were performed in triplicate. The analysis procedures were carried out in the Laboratory of Analysis of Soil, Water and Plant at Universidade Federal Rural do Semi-Arid (UFERSA) in accordance with the Standard Methods for the Examination of Water and Wastewater-SMEWW (American Public Health 
Association [APHA], 2005). The temperature values were determined in situ using a laboratory thermometer (ranging from $-10{ }^{\circ} \mathrm{C}$ to $+110{ }^{\circ} \mathrm{C}$ ) and turbidity using the turbidimeter.

Microbiological analyzes of water were performed using Sterile Disposable specimen cup with lid, Individual, $70 \mathrm{~mL}$ Capacity. Samples were collected directly from wells after flow for 60 seconds. These vials were packed in an ice box cooler for the preservation of the sample, delaying biological changes that occur after removal from the environment. Afterwards, they were taken to the Laboratory of Limnoágua at UFERSA for microbiological analysis. Total and Thermotolerant Coliforms (faecal coliforms) were analyzed according to the methodology of the National Health Foundation (Fundação Nacional de Saúde [FUNASA], 2014).

A completely randomized design with 5 replicates was used, and the means were compared by the Tukey Test at 5\% probability. The Piper Diagram and U.S.S.L. Diagram (United States Salinity Laboratory), were used for the ionic classification and salinity hazard, respectively. In addition, the content of Total Dissolved Solids was estimated. Qualigraf software, version 1.17, 2017 (Fundação Cearense de Meteorologia e Recursos Hídricos [FUNCEME], 2018) was used for all classifications.

\section{Results and Discussion}

The temperature values of underground water ranged $22.0-24.9{ }^{\circ} \mathrm{C}$ (Table 2). There was no significant temperature change to the point of altering water quality, or characterizing it as thermal pollution. Analyzing underground wells in the city of Uba, state of Minas Gerais, Brazil, Moreira, and Condé (2015) found average temperatures similar to these $22{ }^{\circ} \mathrm{C}$ wells. With the objective of evaluating the groundwater quality from deep non-draft tubular wells, in the rural community of the city of Areia, state of Paraiba, Oliveira (2018) found water temperature variation according to the months, in November, December and January water temperatures had reached 27,26 and $24^{\circ} \mathrm{C}$, respectively.

Turbidity ranged 1.02-6.48 NTU when all sampling points were considered. Only underground wells 1 and 2 had turbidity values above the acceptance standard for human consumption (Table 2), according to WHO Consolidation Order $n^{\circ} 5$, of October 3, 2017 by the Ministry of Health (Brasil, 2017). Turbidity above the 5 NTU limit may cause population rejection due to its turbid appearance, but water will not necessarily cause health damage, especially if the water meets other parameters, such as microbiological parameters (absence of total coliforms and Escherichia coli). Turbidity is not a commonly used parameter for analyzing water quality for irrigation. Groundwater generally has low turbidity values, due to soil and rock filtering action (Obiefuna \& Sheriff, 2011).

The results of the chemical analyzes are shown in Table 2. The $\mathrm{pH}$ ranged 7.6-7.9, considered alkaline, and there was no significant difference between the wells. Lópes et al. (2019) analyzing physicochemical parameters water in the community El Comején, Masaya-Nicaragua found similar $\mathrm{pH}$ values (7.81-7.94). There is no restriction on the use of this water in irrigation, since the usual interval in irrigation water is between 6.0 and 8.5 (Almeida, 2010). In the same region of this study, Chapada do Apodi-CE, Fernandes et al. (2005) found lower values than in this study with average $\mathrm{pH} 6.9$ in water underground.

The lowest value electrical conductivity (EC) was $0.76 \mathrm{dS} \mathrm{m}^{-1}$ in well 6 . The other wells were statistically equal with average EC $1.37 \mathrm{dS} \mathrm{m}^{-1}$. There is no health damage or irrigation restrictions. EC values range $0-3.0 \mathrm{dS} \mathrm{m}^{-1}$ have not irrigation restriction (Almeida, 2010). Analyzing groundwater in the municipality of Pombal-PB, Crispim, Oliveira, Chaves, Coelho, and Andrade (2017) found EC values ranged 1.16-1.22 dS m${ }^{-1}$, with an average EC of $1.20 \mathrm{dS} \mathrm{m}^{-1}$. In the Chapada do Apodi-CE, Fernandes et al. (2005) found average values EC 1.95 $\mathrm{dS} \mathrm{m}^{-1}$ higher than that of this study. The groundwater wells 1 and 2 had higher cations values $(22.1$ and 16.6 $\mathrm{mmol}_{\mathrm{c}} \mathrm{L}^{-1}$, respectively) (Table 2). In all wells, the most important contribution was sodium ion $\left(\mathrm{Na}^{+}\right)$. 
Table 2. Physicochemical characteristics mean values of underground water, in Limoeiro do Norte, states Ceará, Brazil

\begin{tabular}{|c|c|c|c|c|c|c|c|c|c|c|c|c|c|c|c|c|}
\hline $\mathbf{N}^{\circ}$ & Temp. & Turbidity & pH & EC & $\mathbf{K}^{+}$ & $\mathrm{Na}^{+}$ & $\mathrm{Ca}^{2+}$ & $\mathbf{M g}^{2+}$ & $\mathrm{Cl}^{-}$ & $\mathrm{CO}_{3}{ }^{2-}$ & $\mathrm{HCO}_{3}^{-}$ & $\mathrm{SO}_{4}{ }^{2-}$ & SAR & Hardness & Cations & Anions \\
\hline & ${ }^{\circ} \mathrm{C}$ & NTU & $\left(\mathrm{H}_{2} \mathrm{O}\right)$ & $\mathrm{dS} / \mathrm{m}$ & \multicolumn{8}{|c|}{ - } & & $\mathrm{mg} / \mathrm{L}$ & \multicolumn{2}{|c|}{---- $\mathrm{mmol}_{\mathrm{c}} \mathrm{L}^{-1}----$} \\
\hline 1 & $23 \mathrm{a}$ & $6.58 \mathrm{a}$ & $7.70 \mathrm{a}$ & $1.26 \mathrm{ab}$ & $0.16 \mathrm{a}$ & $16.84 \mathrm{a}$ & $3.15 b$ & $1.90 \mathrm{~b}$ & $5.20 \mathrm{a}$ & $0.10 \mathrm{a}$ & $4.20 \mathrm{~b}$ & $1.45 \mathrm{ab}$ & $10.6 \mathrm{a}$ & $252.5 b$ & $22.1 \mathrm{a}$ & $10.95 \mathrm{ab}$ \\
\hline 2 & $22 a$ & $6.3 \mathrm{a}$ & $7.80 \mathrm{a}$ & $1.41 \mathrm{a}$ & $0.06 \mathrm{a}$ & $13.27 \mathrm{~b}$ & $2.27 \mathrm{bc}$ & $1.00 \mathrm{~b}$ & $5.20 \mathrm{a}$ & $0.10 \mathrm{a}$ & $7.00 \mathrm{a}$ & $1.50 \mathrm{ab}$ & $10.4 \mathrm{a}$ & $163.5 \mathrm{bc}$ & $16.6 \mathrm{ab}$ & $13.8 \mathrm{a}$ \\
\hline 3 & $22 \mathrm{a}$ & $4.32 \mathrm{~b}$ & $7.90 \mathrm{a}$ & $1.46 \mathrm{a}$ & $0.11 \mathrm{a}$ & $10.14 \mathrm{~b}$ & $2.14 \mathrm{bc}$ & $1.65 \mathrm{~b}$ & $5.80 \mathrm{a}$ & $0.20 \mathrm{a}$ & $5.40 \mathrm{~b}$ & $1.71 \mathrm{a}$ & $7.4 \mathrm{~b}$ & $189.5 \mathrm{bc}$ & $14.0 \mathrm{~b}$ & $13.11 \mathrm{a}$ \\
\hline 4 & $24 \mathrm{a}$ & $1.28 \mathrm{c}$ & $7.60 \mathrm{a}$ & $1.55 \mathrm{a}$ & $0.13 \mathrm{a}$ & $5.93 \mathrm{c}$ & $4.17 \mathrm{a}$ & $3.33 \mathrm{a}$ & $6.40 \mathrm{a}$ & $0.10 \mathrm{a}$ & $3.50 \mathrm{~b}$ & $1.13 \mathrm{~b}$ & $3.1 \mathrm{c}$ & $375 \mathrm{a}$ & $13.6 \mathrm{~b}$ & $11.13 \mathrm{ab}$ \\
\hline 5 & $23 a$ & $1.58 \mathrm{c}$ & $7.80 \mathrm{a}$ & $1.15 \mathrm{ab}$ & $0.12 \mathrm{a}$ & $7.76 \mathrm{c}$ & $1.05 \mathrm{~d}$ & $1.19 \mathrm{~b}$ & $3.80 \mathrm{~b}$ & $0.20 \mathrm{a}$ & $4.60 \mathrm{~b}$ & $1.23 \mathrm{ab}$ & $7.3 \mathrm{~b}$ & $112 \mathrm{c}$ & $10.1 \mathrm{bc}$ & $9.83 b$ \\
\hline 6 & $22 \mathrm{a}$ & $1.02 \mathrm{c}$ & $7.80 \mathrm{a}$ & $0.76 \mathrm{~b}$ & $0.05 \mathrm{a}$ & $3.52 \mathrm{~d}$ & $2.00 \mathrm{~cd}$ & $1.40 \mathrm{~b}$ & $2.40 \mathrm{~b}$ & $0.20 \mathrm{a}$ & $3.80 \mathrm{~b}$ & $0.59 \mathrm{c}$ & $2.70 \mathrm{c}$ & $170 \mathrm{bc}$ & $7.00 \mathrm{c}$ & $6.99 \mathrm{~b}$ \\
\hline $\mathrm{CV}$ & 1.12 & 12.58 & 1.99 & 2.70 & 12.6 & 29.10 & 12.80 & 15.20 & 5.74 & 0.55 & 18.90 & 19.2 & 11.40 & 11.20 & 12.80 & 5.77 \\
\hline
\end{tabular}

Note. Temp. $=$ Temperature, Turbidity $\mathrm{pH}, \mathrm{EC}$ (electrical conductivity), $\mathrm{Na}^{+}$(sodium), $\mathrm{Ca}^{2+}(\mathrm{calcium}), \mathrm{Mg}^{2+}$ (Magnesium), $\mathrm{Cl}^{-}$(chloride), $\mathrm{CO}_{3}{ }^{2-}$ (carbonate), $\mathrm{HCO}_{3}{ }^{-}$(bicarbonate), $\mathrm{SO}_{4}{ }^{2-}$ (sulphate), $\mathrm{SAR}$ (sodium absorption ratio).

Means followed by the same letters do not differ by Tukey test $(\mathrm{P}<0.05)$.

High levels of $\mathrm{Na}^{+}$were observed in wells 1,2 and 3 with values of $16.84,13.27$ and $10.14 \mathrm{mmol}_{\mathrm{c}} \mathrm{L}^{-1}$, corresponding to 387,305 and $233 \mathrm{mg} \mathrm{L}^{-1}$, values considered above permitted for drinking water, whose limit is $200 \mathrm{mg} \mathrm{L}^{-1}$ (WHO, 2011). Considering water for irrigation, wells 1 and 2 have severe restrictions for use by sodium absorption ratio (SAR) and $\mathrm{Na}^{+}$content, whose severity limit is $9 \mathrm{mmol}_{\mathrm{c}} \mathrm{L}^{-1}$ for both (Almeida, 2010, p.7). Probably, the higher sodium contents are due to higher water withdrawals from these underground wells, associated to the low rainfall period, as a consequence the salts become more concentrated, indicating that they need to be cautious about the use of this water for irrigation, choosing crops adapted to these conditions. In the municipality of Limoeiro do Norte, Ceará states, Barroso et al. (2010) found lower $\mathrm{Na}^{+}$values than in this study 9.03 and $8.03 \mathrm{mmol}_{\mathrm{c}} \mathrm{L}^{-1}$, in the months of July and August, respectively. In the Chapada do Apodi-CE, Fernandes et al. (2005) found $\mathrm{Na}^{+}$values ranged $65.4-160.6 \mathrm{mg} \mathrm{L}^{-1}$, corresponding to 2.84 to $6.98 \mathrm{mmol}_{\mathrm{c}} \mathrm{L}^{-1}$. Of all cations, Lópes et al. (2019) also found higher levels of sodium in water, but with lower values $\left(48.6 \mathrm{mg} \mathrm{L}^{-1}\right)$ than this study.

For the potassium contents, there was no significant difference between the wells, and the values ranged 0.05-0.16 $\mathrm{mmo}_{\mathrm{c}} \mathrm{L}^{-1}$ (Table 2). The highest contents of calcium, magnesium and water hardness were found in well $4\left(4.17,3.33 \mathrm{mmol}_{\mathrm{c}} \mathrm{L}^{-1}\right.$ and $375 \mathrm{mg} \mathrm{L}^{-1}$, respectively). Potassium is an essential element in humans and is seldom, if ever, found in drinking water at levels that could be a concern for healthy humans. The recommended daily requirement is greater than $3000 \mathrm{mg}$ (WHO, 2011, p. 412).

The water hardness can originate naturally (dissolution of calcareous rocks, calcium and magnesium-rich) or anthropogenic (industrial dumping). The $\mathrm{Ca}^{2+}$ and $\mathrm{Mg}^{2+}$ ions under supersaturation conditions react with water anions forming precipitates, which contribute to increase water hardness, especially when associated with carbonates and/or bicarbonates. In all wells the total hardness ranged 112-375 mg L $\mathrm{mg}^{-1}$, but no samples exceeded the recommended value for drinking water in according to Consolidation Order $\mathrm{n}^{\circ} 5$ by the Ministry of Health (Brasil, 2017), which has the maximum permissible hardness value total for drinking water of $500 \mathrm{mg} \mathrm{L}^{-1}$ of $\mathrm{CaCO}_{3}$. Analyzing water quality for irrigation, according to Nakayama and Bucks (1986) wells 1, 2, 3 and 6 are considered medium hard, well 4 is very hard and well 5 soft. In general, groundwater has high hardness as one of its peculiarities (Rodrigues Neto, 2014).

The water hardness and higher $\mathrm{Ca}^{2+}, \mathrm{Mg}^{2+}$ and bicarbonates contents originate from the dissolution of carbonate rocks from the Jandaíra Formation. This geomorphological unit belongs to the Potiguar Basin that is composed stratigraphcally, at emerged portion by the Jandaíra Formation (250-300 m thick) above the Açu formation. The first is composed by calcitic and dolomitic limestone rocks, whereas the second Açu Formation is composed of fine-grained sandstone, with micaceous and kaolinitic clay mineralogy (R. Girão, Moreira, A. Girão, Romero, \& Ferreira, 2014; Oliveira et al., 2018). This formation constitutes a karst aquifer, where water storage and circulation occur in cracks open by calcareous rocks dissolution, and is limited at the base by clayey levels of the Açu Formation (Fernandes et al., 2005).

For total anions, the lowest values were found in wells 5 and $6\left(9.83\right.$ and $\left.6.99 \mathrm{mmo}_{\mathrm{c}} \mathrm{L}^{-1}\right)$, although they did not differ statistically from wells 1 and 4. Analyzing each ion individually, for chloride $\left(\mathrm{Cl}^{-}\right)$lower values were found in wells 5 and 6 (3.8 and $2.4 \mathrm{mmo}_{\mathrm{c}} \mathrm{L}^{-1}$, respectively) (Table 2). None of the water samples exceeded the recommended value for drinking water in according to Consolidation Order $n^{\circ} 5$ (Brasil, 2017), which has the 
maximum permissible chloride total value of $250 \mathrm{mg} \mathrm{L}^{-1}$ which is equivalent to $7.05 \mathrm{mmol}_{\mathrm{c}} \mathrm{L}^{-1}$. For irrigation use, except for well 6 , the other wells have a slight to moderate restriction for irrigation, according to Nakayama and Bucks (1986).

For the carbonate $\left(\mathrm{CO}_{3}{ }^{2-}\right)$ values ranged $0.10-0.20 \mathrm{mmo}_{\mathrm{c}} \mathrm{L}^{-1}$ and there was no significant difference between the wells. For bicarbonate $\left(\mathrm{HCO}_{3}^{-}\right)$the highest value was found in well $2\left(7.0 \mathrm{mmol}_{\mathrm{c}} \mathrm{L}^{-1}\right)($ Table 2). There are no severe restrictions on carbonate or bicarbonate content for irrigation (Nakayama \& Bucks, 1986). Barroso et al. (2010) found lower values for bicarbonate in groundwater in Limoeiro do Norte-CE (1.72 to $\left.1.95 \mathrm{mmol}_{\mathrm{c}} \mathrm{L}^{-1}\right)$. For sulphate $\left(\mathrm{SO}_{4}{ }^{2-}\right)$ the lowest value was in well $6\left(0.59 \mathrm{mmo}_{\mathrm{c}} \mathrm{L}^{-1}\right)$. Sulphate contents ranged 1.71-0.59 $\mathrm{mmo}_{\mathrm{c}}$ $\mathrm{L}^{-1}$, corresponding to 82.08 to $28.32 \mathrm{mg} \mathrm{L}^{-1}$, values below that considered damage to drinking water according to Consolidation Order n ${ }^{\circ} 5$ (Brasil, 2017), which is $250 \mathrm{mg} \mathrm{L}^{-1}$.

Total dissolved solids (TDS) combine the sum of all ion particles that are smaller than 2 microns $(0.0002 \mathrm{~cm})$. This includes all of the disassociated electrolytes that make up salinity concentrations, as well as other compounds such as dissolved organic matter. Their presence is associated with sewage dumps, altering organoleptic quality of drinking water, causing rejection for human consumption. The TDS values estimated by the Qualigraf software ranged from $494-1,007.5 \mathrm{mg} \mathrm{L}^{-1}$ (Table 3). The drinking water standard for TDS is at most $1000 \mathrm{mg} \mathrm{L}^{-1}$, with only well 4 reaching this value. For the classification of waters by this criterion, except for well 6 that was classified as freshwater, all other wells were classified as brackish water, based on resolution Conselho Nacional de Meio Ambiente [CONAMA] (2005).

Table 3. Total dissolved solids (TDS) values estimated by Qualigrafi 2017 and classification of underground water in Limoeiro do Norte, states Ceará, Brazil

\begin{tabular}{lll}
\hline Number of underground wells & TDS & Classification \\
\hline- & $\mathrm{mg} \mathrm{L}^{-1}$ & - \\
1 & 819.0 & Brackish water \\
2 & 916.5 & Brackish water \\
3 & 949.0 & Brackish water \\
4 & $1,007.5$ & Brackish water \\
5 & 747.5 & Brackish water \\
6 & 494.0 & Freshwater \\
\hline
\end{tabular}

Note. Classification based on resolution CONAMA (2005).

Piper diagrams (Figure 1) showed the dispersion of the cation $\left(\mathrm{Ca}^{2+}, \mathrm{Mg}^{2+}\right.$ and $\left.\mathrm{K}^{+}+\mathrm{Na}^{+}\right)$and anion $\left(\mathrm{HCO}_{3}{ }^{-}, \mathrm{Cl}^{-}\right.$ $+\mathrm{NO}_{3}{ }^{-}$and $\left.\mathrm{SO}_{4}{ }^{2-}\right)$ content in groundwater samples. In the cation $(\mathrm{Ca} / \mathrm{Mg} / \mathrm{Na}+\mathrm{K})$ triangle, $83 \%$ of the water samples were classified as sodium, and only $17 \%$ do not contain any dominant cation. In the triangular diagram concerning anions, $50 \%$ samples do not contain any dominant anion, $33 \%$ bicarbonate, and $17 \%$ chloride. In the general classification, water from wells 1, 3 and 5 were classified as sodium chloride, 2 and 6 were classified as sodium bicarbonate and well 4 as calcium magnesium sulfate. Barroso et al. (2010) classified groundwater in the municipality of Limoeiro do Norte-CE as $47.5 \%$ sodium bicarbonate, $40.0 \%$ sodium chloride. The sodium content was higher than the other cations and, the bicarbonate and chloride higher than the other anions, as well as in this study. 


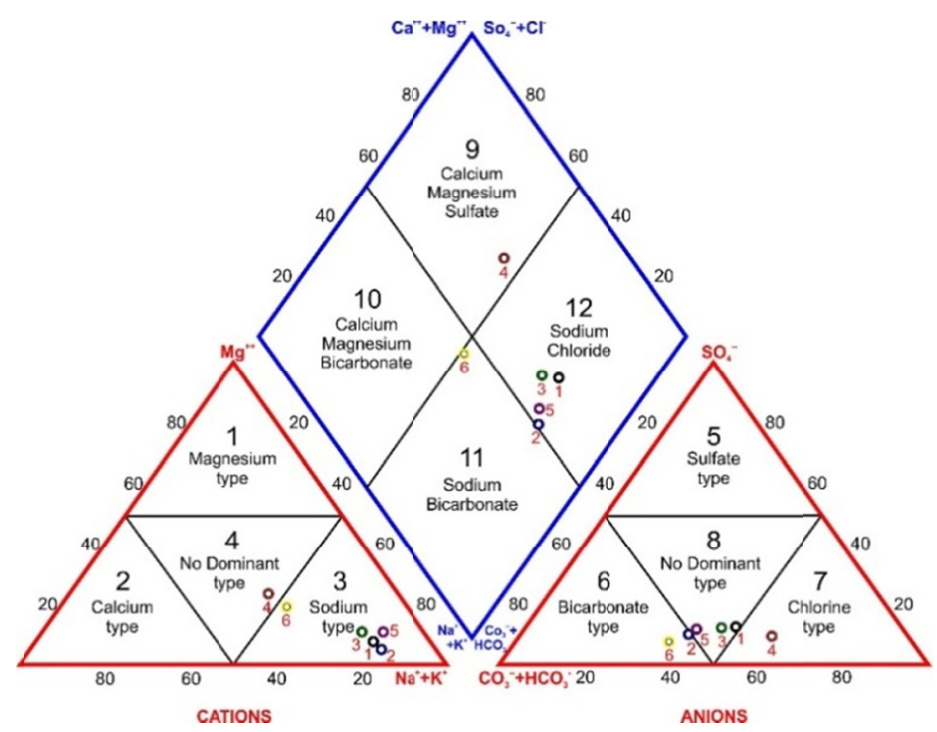

Figure 1. Results of groundwater analyses plotted in a piper diagram

Irrigation water is classified based upon the sodium adsorption ration (SAR) and electrical conductivity (EC). Sodium is one of the important parameter governing the water quality as its excess can deteriorate the soil quality and may cause damage to the sensitive crops. The behavior of sodium is expressed with respect to calcium and magnesium through a ratio commonly known as sodium absorption ratio (SAR) following formula (U.S. Salinity Laboratory, 1954):

$$
\mathrm{SAR}=\frac{\mathrm{Na}^{+}}{\sqrt{\frac{\mathrm{Ca}^{2+}+\mathrm{Mg}^{2+}}{2}}}
$$

Electrical Conductivity and SAR values were plotted on US salinity diagram that indicated in general the groundwater samples fall in C3S1 or C3S2 category with high salinity (C3) and low sodium (S1) ou medium sodium (S2) hazard (Figure 2). Wells 4 and 6 fall in C3-S1 category. High salinity water C3 cannot be used on soils which restricted drainage and it may require special salinity control practices, and therefore, to select vegetable species tolerant to salts. For sodium, this water can be used for irrigation, with little probability of reaching dangerous levels of exchangeable sodium (Almeida, 2010). Wells 1, 2, 3 and 5 fall in C3-S2 category. In this case for sodium, in fine textured soils, high cation exchange capacity and poor leaching can be a hazard, because it can increase $\mathrm{Na}^{+}$and decrease other cations, unless the soil contains gypsum. The use of these waters is recommended in soils with a more sandy texture or in organic soils of good permeability. 


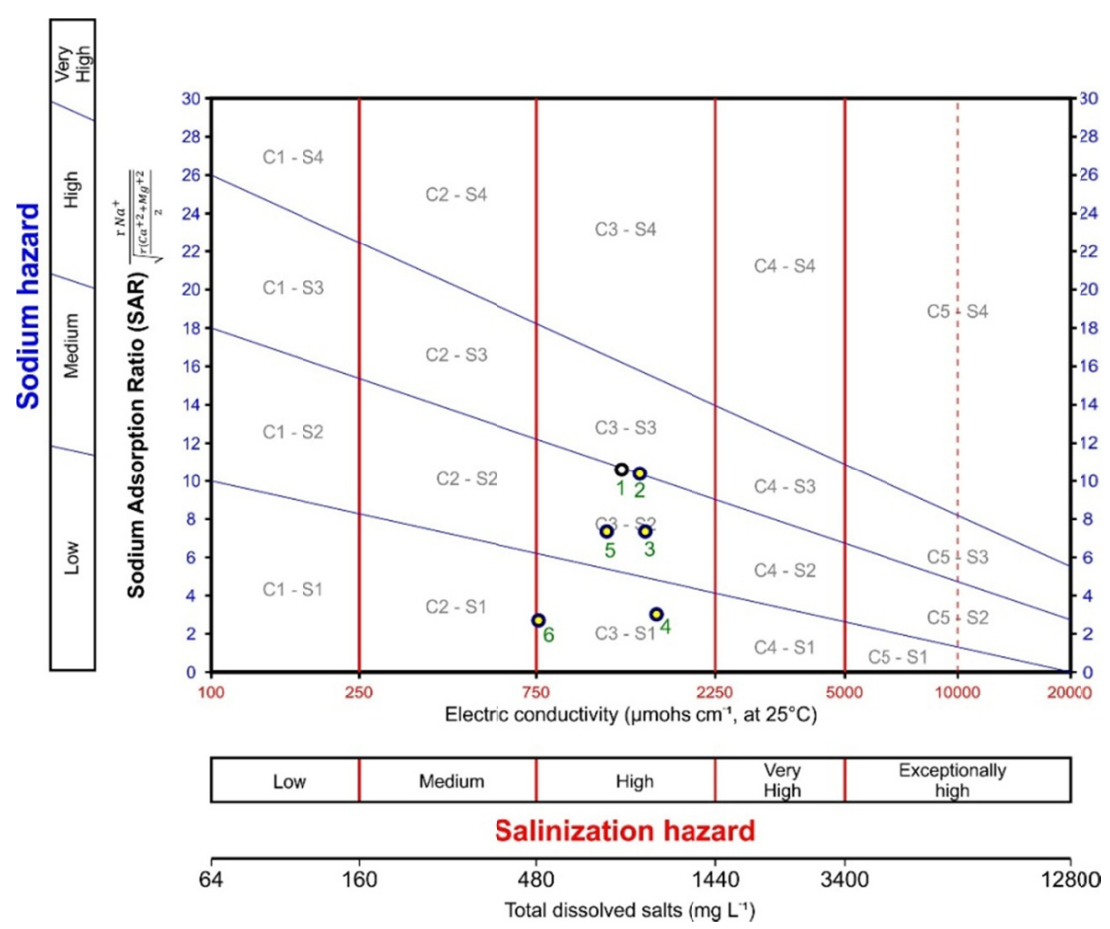

Figure 2. U.S. Salinity Laboratory classifications for irrigation water

For the microbiological quality analysis of the water, the technique of detection of specific microorganisms was used, whose presence may indicate the possibility of occurrence of infections. Drinking water must not have Thermotolerant coliforms, and $<1.1 \mathrm{MPN} \mathrm{g}^{-1}$ (most probable number) or absent for Total coliforms.

All groundwater samples were positive for Total coliforms and one sample (well 5) was positive for Thermotolerant coliforms. In well 5 was found $23 \mathrm{MPN} \mathrm{g}^{-1}$ for both Total and coliforms. All others were $3 \mathrm{MPN}$ $\mathrm{g}^{-1}$ for total coliforms, and absent for Thermotolerant coliforms (Table 4). This was probably because in the area of well 5, near the water withdrawal site, the farmer uses organic fertilization with animal manure in the fruit, and irrigation by flooding. Thus, these factors associated with the fact that the soil is of a sandy texture with only $222 \mathrm{~g} \mathrm{~kg}^{-1}$ of clay and the rain, favored the infiltration of water contaminated with Thermotolerant coliforms to groundwater.

Table 4. Total and Thermotolerant coliforms of six-well groundwater in the municipality of Limoeiro do Norte, Ceará State, Brazil

\begin{tabular}{lll}
\hline $\mathbf{N}^{\circ}$ Poços & Coliformes totais (NMP/g) & Coliformes Thermotolerant (NMP/g) \\
\hline & $\mathrm{mg} \mathrm{L}^{-1}$ & Absent \\
1 & 3 & Absent \\
2 & 3 & Absent \\
3 & 3 & Absent \\
4 & 3 & Absent \\
5 & 23 & 23 \\
6 & 3 & Absent \\
\hline
\end{tabular}

Note. $\mathrm{MPN}=$ most probable number.

\section{Conclusion}

Based on the average chemical element concentration $\left(\mathrm{mmol}_{\mathrm{c}} \mathrm{L}^{-1}\right)$ in the groundwater, the following quantification is obtained: $\mathrm{Na}^{+}>\mathrm{Ca}^{2+}>\mathrm{Mg}^{2+}>\mathrm{K}^{+}$for cations. For anions there was a change in the the wells, for the 1,3 and $4 \mathrm{Cl}^{-}>\mathrm{HCO}_{3}{ }^{-}>\mathrm{SO}_{4}{ }^{2-}>\mathrm{CO}_{3}{ }^{2-}$ and wells 2,5 and $6 \mathrm{HCO}^{3-}>\mathrm{Cl}^{-}>\mathrm{SO}_{4}{ }^{2-}>\mathrm{CO}_{3}{ }^{2-}$. The wells 1,2 and 3 have severe restrictions for use by SAR (sodium absorption ratio) and $\mathrm{Na}+$ content, indicating that they 
need to be beware about the use of this water for irrigation, choosing crops adapted to these conditions. Data were collected during the dry period which may have favored nutrient concentration.

Water from wells 1, 3 and 5 were classified as sodium chloride, 2 and 6 were classified as sodium bicarbonate and well 4 as calcium magnesium sulfate. With the exception of well 6 classified as freshwater, all other wells were classified as brackish water. Groundwater samples fall in $\mathrm{C} 3 \mathrm{~S} 1$ or $\mathrm{C} 3 \mathrm{~S} 2$ category with high salinity and low or medium sodium hazard. With the exception of $\mathrm{Na}^{+}$, whose value was above the limit allowed, no well with groundwater was detected chemical hazard for human consumption. There was the detection of Total coliforms, but in well 5 the presence of Thermotolerant coliforms was detected.

When the pathogen is detected, long-term assessments are imperative for understanding the introduction, transport, and survival of indicator and pathogenic organisms. Furthermore, when performed on a larger scale, such information can be used to develop both statistical and dynamic models to predict when high levels of particular organisms may be present. With scientific validation at the local level, the combination of physical modeling and real-time measurements could prove more effective than the microbial indicator system at preventing human exposure to a wide variety of harmful agents.

\section{References}

Almeida, O. A. (2010). Qualidade da água de irrigação-Dados eletrônicos (p. 234). Embrapa Mandioca e Fruticultura, Cruz das Almas, BA. Retrieved from https://ainfo.cnptia.embrapa.br/digital/bitstream/ item/26783/1/livro-qualidade-agua.pdf

Alvares, C. A., Stape, J. L., Sentelhas, P. C., Alves, J. L. M. G., \& Sparovek, G. (2014). Köppen's climate classification map for Brazil. Meteorologische Zeitschrift, 22(6), 711-728. https://doi.org/10.1127/ 0941-2948/2013/0507

APHA (American Public Health Association). (2005). Standard methods for the examination of water and watwater (21st ed.). Washington, USA.

Barroso, A., Ness, R. L. L., Gomes Filho, R. R., Silva, F. L., Chaves, M. J. L., \& Lima, C. A. (2010). Avaliação qualitativa das águas subterrâneas para irrigação na região do Baixo Jaguaribe-Ceará. Revista Brasileira de Agricultura Irrigada, 4(3), 150-155. https://doi.org/10.7127/rbai.v4n300011

Brasil. (2017). Portaria de Consolidação $N^{o} 5$ do Ministério da Saúde de 03 de outubro de 2017. Brasília: Ministério da Saúde. Retrieved from https://cevs-admin.rs.gov.br/upload/arquivos/201804/26143402anexo-xx.pdf

CONAMA (Conselho Nacional de Meio Ambiente). (2005). Resolução CONAMA 357, de 18/03/2005: Water classification. Retrieved June 12, 2018, from http://www2.mma.gov.br/port/conama/legiabre.cfm? codlegi $=459$

Crispim, D. L., Oliveira, A. M. B. M., Chaves, A. D. G., Coelho, L. F. O., \& Andrade, S. O. (2017). Análise Físico-Química das Águas de Três Poços Amazonas no Centro da Cidade de Pombal-PB. Geografia, Ensino \& Pesquisa, 21(2), 155-163. https://doi.org/10.5902/2236499422445

Eckhardt, R. R., Diedrich, V. L., Ferreira, E. R., Strohschoen, E., \& Demaman, L. C (2008). Mapeamento e avaliação da potabilidade subterrânea do município de Lajeado, RS, Brasil. Ambiente \& Água-An Interdisciplinary Journal of Applied Science, 4(1), 58-80. https://doi.org/10.4136/ambi-agua.74

FAO (Food and Agricultural Organization of the United Nations). (2017). Fresh groundwater withdrawal (primary and secondary) (2013-2017). FAO, Brazil. Retrieved from http://www.fao.org/nr/water/aquastat/ data/query/results.html

FAO (Food and Agricultural Organization of the United Nations). (2011). The State of the World's Land and Water Resources for Food and Agriculture: Managing Systems at Risk. Retrieved from http://faostat.fao.org/docrep

Fernandes, M. A. B., Santiago, M. M. F., Gomes, D. F., Mendes Filho, J., Frischkorn, H., \& Lima, J. O. G. (2005). A origem dos cloretos nas águas subterrâneas na chapada do Apodi-Ceará. Águas Subterrâneas, 19(1), 25-34. https://doi.org/10.14295/ras.v19i1.1349

FUNASA (Fundação Nacional de Saúde). (2014). Manual de controle da qualidade da água para técnicos que trabalham em ETAS (1st ed., p. 112). Brasília, Brazil.

FUNCEME (Fundação Cearense de Meteorologia e Recursos Hídricos). (2018). QualiGraf, 2018. Governo do Ceará. Retrieved April 22, 2018, from http://www3.funceme.br/qualigraf/mi/midia/show/3 
Girão, R. O., Moreira, L. J. S., Girão, A. L. A., Romero, R. E., \& Ferreira, T. O. (2014). Soil genesis and iron nodules in a karst environment of the Apodi Plateau. Revista Ciência Agronômica, 45(4), 683-695. https://doi.org/10.1590/S1806-66902014000400006

López, D. N. M., Fernández, I. M., Maldonado, S. A. S., Díaz, F. L. A., \& Alemán, L. A. B. (2019). Indicator of quality of water for human consumption in the Community El Comején, Masaya (Nicaragua). Journal of Agricultural Science, 11(8), 176-182. https://doi.org/10.5539/jas.v11n8p176

MMA (Ministério do Meio Ambiente). (2018). Retrieved November 12, 2018, from http://www.mma.gov.br/ estruturas/sedr_proecotur/publicacao/140_publicacao09062009025910.pdf

Morais, L. F. S., Rocha Filho, F. C., Cordeiro W., Figueiredo, M. C. B., \& Rosa, M. F. (2005). Análise das águas subterrâneas nos municípios do Médio e Baixo Jaguaribe: Mapeamento e estimativa da disponibilidade atual. Revista Ciência Agronômica, 36(1), 34-43. Retrieved from http://www.ccarevista.ufc.br/seer/ index.php/ccarevista/article/view/5/6

Moreira, D. A., \& Condé, N. M. (2015). Qualidade das águas de minas no perímetro urbano do município de Ubá-MG. Multi-Science Journal, 1(1), 84-89. https://doi.org/10.33837/msj.v1i1.45

Nakayama, F. S., \& Bucks, D. A. (1986). Trickle irrigation for crop production (1st ed., Vol. 9, pp. 156-157). Phoenix: Agricultural Research Service, U.S. Water Conservation Laboratory.

Obiefuna, G. I., \& Sheriff, A. (2011). Assessment of Shallow Ground Water Quality of Pindiga Gombe Area, Yola Area, NE, Nigeria for Irrigation and Domestic Purposes. Research Journal of Environmental and Earth Sciences, 3, 131-141. Retrieved from http://maxwellsci.com/print/rjees/v3-131-141.pdf

Oliveira, D. P., Sartor, L. R., Souza Júnior, V. S., Corrêa, M. M., Romero, R. E., Andrade, G. R. P., \& Ferreira, T. O. (2018). Weathering and clay formation in semi-arid calcareous soils from Northeastern Brazil. CATENA, 162, 325-332. https://doi.org/10.1016/j.catena.2017.10.030

Oliveira, V. S. (2018). Qualidade de água de poços tubulares utilizada no cultivo de hortaliças (Work of Conclusion of Course of Agronomy, University Federal of Paraíba, Brazil). Retrieved from https://repositorio.ufpb.br/jspui/bitstream/123456789/3548/1/VSO02032018.pdf

Rodrigues Neto, M. P. (2014). Estudo da Qualidade de Águas de Poços no Iguape-CE (Master's thesis, University Federal of Ceará, Fortaleza, Brazil). Retrieved from http://www.repositorio.ufc.br/bitstream/riufc/11437/ $1 / 2014$ dis mprodriguesneto.pdf

Silva, D. D., Migliorini, R. B., Silva, E. C., Lima, Z. M., \& Mouras, I. B. (2014). Falta de saneamento básico e as águas subterrâneas em aquífero freático: Região do Bairro Pedra Noventa, Cuiabá (MT). Engenharia Sanitária e Ambiental, 19(1), 43-52. https://doi.org/10.1590/S1413-41522014000100005

USSL (U.S. Salinity Laboratory). (1954). Classification of irrigation waters (Circu 969). US Department of Agriculture, Washington.

WHO (World Health Organization). (2011). Guidelines for drinking-water quality (4th ed.). Retrieved from https://apublica.org/wp-content/uploads/2014/03/Guidelines-OMS-2011.pdf

\section{Copyrights}

Copyright for this article is retained by the author(s), with first publication rights granted to the journal.

This is an open-access article distributed under the terms and conditions of the Creative Commons Attribution license (http://creativecommons.org/licenses/by/4.0/). 